\title{
Considerations about bisphosphonate therapy and patients using dental prosthesis: a literature review
}

\author{
Ananda da Silva Maganhoto 1*, Túlio Garcia Margute 2, Thiago Quirino Mota da Silva 3, Andrei \\ Rabenschlag Rosato 4, Igor Fonseca dos Santos 5, Tiago Garcia Margute 6
}

\author{
${ }^{1}$ Uningá, Maringá, Paraná, PR, Brazil. \\ ${ }^{2}$ Ulbra, Torres, Rio Grande do Sul, RS, Brazil \\ ${ }^{3}$ CEUMA, São Luis, Maranhão, MA, Brazil. \\ ${ }^{4}$ São Leopoldo Mandic, Campinas, São Paulo, SP, Brazil. \\ ${ }_{5}^{5}$ Unirg, Gurupi, Tocantins, TO, Brazil. \\ ${ }^{6}$ UNG, Guarulhos, São Paulo, SP, Brazil.
}

${ }^{*}$ Corresponding author: Tiago Garcia Margute. Av. Nereu Ramos, nº101 - Centro. Zip Code: 88960-000 - Santa Catarina, Brazil. Phone: +55 (48) 9 9919-9905. E-mail: tiagomargute@hotmail.com

Received on: Jul 27, 2021. Accepted on: Aug 5, 2021. Available online: Aug 9, 2021.

\begin{abstract}
Bisphosphonates are drugs used for treatment of many medical diseases; their prescription has increased over the years due to the various indications for use. They come in two distinct groups: containing nitrogen (alendronate, ibandronate, pamidronate, risedronate and zolendronate) and without nitrogen in their composition (etidronate and tiludronate). Despite being used in the treatment of several diseases, they can lead to the development of osteonecrosis in the patient's maxilla and/or mandible, when submitted to dental procedures, such as extractions, surgeries or traumas for non-adapted prostheses. It is recommended that patients who use bisphosphonates visit the dentist at least once a year, for better control and monitoring of oral health.
\end{abstract}

Keywords: Bisphosphonates; Osteonecrosis; Dental prosthesis.

\section{Introduction}

Bisphosphonates (BFs) are drugs used to treat various medical illnesses; their prescription has increased over the years due to the various indications for use. They are used to control some diseases, such as osteoporosis, Paget's disease, myelomas, bone metastases.

They are analogous to pyrophosphates, with the replacement of a carbon atom by an oxygen atom, and pyrophosphates are chemical compounds that physiologically 
Considerations about bisphosphonate therapy and patients using dental prosthesis

regulate bone calcification and resorption [1].

As they are synthetic analogues of pyrophosphates, BFs have a high affinity for hydroxyapatite crystals, targeting the mineral portion of bone tissue [2]. Due to this great affinity for mineralized tissues, they act in sites of great bone formation and resorption. Through these characteristics, a study of the use of these drugs in the treatment of bone diseases was initiated [3].

BFs are considered safe drugs, with the objective of preventing bone resorption [4]. Despite being used in the treatment of several diseases, they can lead to the development of osteonecrosis in the patient's maxilla and/or mandible, when submitted to dental procedures, such as extractions, surgeries or traumas [5].

The BFs are presented in two distinct groups: containing nitrogen (alendronate, ibandronate, pamidronate, risedronate and zolendronate) and not containing nitrogen in its composition (etidronate and tiludronate) [6]. Freitas et. al. [7] divided the BFs into first, second and third generation groups, the first generation being those that do not have nitrogen (clodronate, etidronate and tiludronate,) and the second and third generation groups that contain nitrogen (alendronate; pamidronate; ibandronate, and risendronate and zoledronate, respectively). The second and third generation BFs differ from the first group, as they strongly adhere to the mineral hydroxyapatite present in the bone tissue.

They are medications known for their long half-lives. Alendronate, for example, has a half-life of eleven years and nine months [8]. The authors Marx, Cillo and Ulloa [2] also reported that the effects of bisphosphonates can remain in the body for approximately ten years. This is because BFs manage to lodge for a long time within the bone matrix. Through their action on osteoclasts, they produce a reduction in bone resorption, thus predominating the bone formation process, in which a positive calcium balance and bone mass gain are achieved [9].

These drugs are prescribed by specialist physicians, usually gynecologists, hematologists, urologists, however, osteonecrosis in the jaws caused by the use of bisphosphonates $(\mathrm{BRONJ})$ is most often reported in articles in the dental field [10]. Osteonecrosis is a clinical condition characterized by bone necrosis, resulting from systemic and local factors that compromise bone vascularization [11]. his bone necrosis can be due to poor healing of bone tissue in the jaws after an invasive dental procedure or it can occur spontaneously without any apparent triggering factor. Some risk factors specific to this bone pathology 
can be described, such as radiotherapy to the head and neck, advanced periodontal disease, oral procedures involving bone surgery, edentulous regions and chronic trauma caused by poorly fitted prostheses [12].

Due to the direct relationship between the use of BFs and dental procedures that involve bone remodeling, it is necessary that the dentist has knowledge about these to correctly manage the patient, avoiding damage to the oral cavity [13].

\section{Methodology}

The bibliographic research developed was exploratory, qualitative and descriptive [14]. Qualitative research can be defined as a nonstatistical study, which identifies and analyzes in depth data that are difficult to measure from a certain group of individuals in relation to a specific problem.

To achieve the objective of this study, bibliographic research from secondary sources was used as a method. For [15] bibliographic research is developed from material already prepared, consisting mainly of books and scientific articles, in addition to texts disseminated by magnetic and electronic texts, seeking to explain a problem, from published theoretical references, with the intention of collecting knowledge about a problem, constituting the basic process for monographic studies.

The collection source was the database of the Scielo and Pubmed search sites using the keywords Bisphosphonates; osteonecrosis; dental prosthesis. Journals that were in Portuguese and English were selected, with a predominance area in dentistry and dated from 2001.

\section{Results (Review)}

\section{Bisphosphonates and their pharmacology}

BFs began to be used around 1960 as a treatment for several diseases, such as bone metastases, lung cancer, multiple myeloma, Paget's disease, control of calcium metabolism diseases, and mainly in the treatment and prevention of osteoporosis. It is estimated that between May 2003 and April 2004, 22 million prescriptions for alendronate occurred in the US, making it the most prescribed drug for the treatment of osteoporosis in the world [16].

BFs are synthetic analogues of inorganic pyrophosphate, in which the central oxygen atom (P-O-P) is replaced by a central carbon atom (P-C-P). Pyrophosphates are chemical compounds present in the body of all individuals, responsible for the physiological regulation of calcification and bone resorption [13]. They present 
in their chemical structure two phosphate groups (PO3) covalently bonded to a central carbon, plus two chains generically called R1 and R2. The short first chain is responsible for the chemical and pharmacokinetic properties of $\mathrm{BFs}$, in addition to conferring, together with the phosphate groups, high affinity to bone tissue. The long R2 chain, on the other hand, determines the anti-resorptive potency and the pharmacological mechanism of action [17].

BFs are divided into two categories of chemical structures of the R2 chains, nitrogen and non-nitrogen. Nitrogen is not metabolized and accumulate in bone tissue, and thus remain active for many years. Therefore, they are considered more potent than non-nitrogenous [18].

There are three types of $\mathrm{BF}$ generations: first generation or nonnitrogen, second generation or nitrogen, and third generation or zoledronic acid. Within the first-generation group are etidronate, clodronate and tiludronate, which weakly bind to hydroxyapatite crystals. The second-generation ones, comprised of alendronate, pamidronate and ibandronate, are about 10 to 1000 times more potent than the firstgeneration ones. Finally, risendronate and zoledronate are considered third generation, are 100 to 850 times superior to pamidronate, and the most potent among those already submitted to in vitro and in vivo tests [19].

BFs can be administered orally or intravenously. BFs for oral use are poorly absorbed by the body through the gastrointestinal tract. At the end of the process, the bioavailability is less than $1 \%$ in most types. The plasma halflife of BFs is quite short, ranging from 30 minutes to two hours, however, after being absorbed by bone tissue, it can remain for more than 10 years in skeletal tissues. However, once new bone tissue is deposited on layers containing bisphosphonates, the effect on osteoclasts decreases if drug use is discontinued [13]. Some side effects can be described, such as inflammation in the esophagus, bone pain in the maxillofacial region [20].

Intravenous BFs have greater potency, inducing a greater risk of developing osteonecrosis. This is the risk directly proportional to the time of use of the drug [21-22]. This pathway has a faster absorption, the drug is available more quickly to deposit in the bone [23].

Osteonecrosis associated with the use of bisphosphonates

Osteonecrosis of the jaws was first described in 2003 by Robert E. Marx, who described this side effect in patients taking Pamidronate and Zoledronate [24]. 
Patients can be classified in this condition based on three characteristics: current or previous treatment with BFs, necrotic bone exposed in the maxillary or mandibular region for more than eight weeks, with no history of radiation therapy in these regions [25].

\section{Clinically,}

osteonecrosis associated with the use of BFs is similar to osteoradionecrosis, there is destruction of the oral mucosa that leads to bone exposure in the maxilla or mandible, generating necrotic content. This necrosis may present with or without pain. Associated with this clinical picture, other signs and symptoms may also appear, such as gingival redness, edema, suppuration, dental mobility of the adjacent elements, paresthesia, enlarged lymph nodes close to the region in question, as well as sinusitis and nasal secretion as well. [26].

Some systemic factors may be related to osteonecrosis: diabetes; immunosuppression; other drugs such as chemotherapy and corticosteroids. [27]. Progressive osteonecrosis, with subsequent involvement of adjacent teeth, leads to poor oral hygiene of the elements close to the lesion. This poor hygiene facilitates the infection at the site, making the episode of necrosis more extensive, leading to mobility and tooth loss [25].
Osteonecrosis is relatively common in the mandible, as the site is often exposed to the external environment during extractions, major dental procedures and during oral hygiene [28]. Some authors believe that this predilection is due to the fact that this is the only bone tissue submitted to continuous trauma and exposed to the environment through the gingival sulcus, justifying the high percentage of cases triggered by tooth extractions. The risk of osteonecrosis increases with dental manipulation and poor oral hygiene, so that, when the bone structure is exposed to the oral microbiota, there is an increase in infection, producing significant pain, swelling, purulent secretion and progressive bone necrosis that is very difficult to be treated [29-30].

There are events that can lead to the development of BF-related osteonecrosis have been determined: wounds that do not heal after extractions; soft tissue injuries caused by ill-fitting dentures that do not heal; osteomyelitis caused by implants and spontaneous causes [31].

The factor considered as the main triggering factor for osteonecrosis is tooth extraction, but other factors, such as untreated periodontal disease; mucosal trauma due to maladaptation of prostheses; patients with compromised immune system, 
Considerations about bisphosphonate therapy and patients using dental prosthesis

implants, apical and periodontal surgery with bone exposure, diabetes, obesity, alcoholism, smoking, poor oral hygiene, use of corticosteroids, anemia, atherosclerosis, age above 65 years, use of chemotherapy drugs, use of BFs for more than three years, type of BFs used, coagulation disorders, are conditions that can favor or trigger the necrosis event [32-40].

\section{Dental prosthesis and the use of bisphosphonates}

Dental prosthesis is an alternative dental treatment that improves chewing, phonation, swallowing and the self-esteem of patients who have suffered tooth loss [41-42]. The high incidence of tooth loss is a reality that is still present in many patients, despite all health education and prevention in Dentistry.

Tooth loss, in addition to altering the stomatognathic system, can generate other systemic ones, due to limitations in masticatory function and to consuming a balanced diet. Rehabilitation with a dental prosthesis enables the restoration of these lost functions, in addition to improving the patient's esthetics. The adaptation of the prosthesis must be the best possible, so as not to lead to a failure of function, and consequently to mucosal injuries [43].
Osteonecrosis induced by BFs is characterized by the incapacity of the affected bone tissue to repair and remodel itself in the face of inflammatory conditions triggered by mechanical stress (chewing), extractions, irritations caused by prostheses or dental and periodontal infection [44].

The study by Gegler et al. [45] reported that, in addition to recent tooth extraction, one of the reasons that triggered osteonecrosis was trauma to the oral mucosa after the installation of a removable partial denture in patients using BFs. Dotto and Dotto [46] also mentioned that in their study, two patients who were undergoing therapy with the use of BFs complained of discomfort and pain when using dental prostheses. Aiex et al. [47] mentioned that in July 2010 a patient sought dental care due to pain in the gums, diagnosed with osteonecrosis associated with the use of BFs in the mandible, on the right side, due to the use of an ill-fitting dental prosthesis. Thus, poorly fitted dental prostheses can facilitate the emergence of osteonecrosis in patients who use bisphosphonates.

It is necessary for the dentist to pay attention after installing a prosthesis in patients with a history of using BFs. Patients using removable dentures should be constantly examined for trauma zones produced by poorly fitted prostheses, especially on the 
lingual surface of the alveolar crests. [48].

Ricon et al. [49] commented that a careful examination should be carried out in edentulous patients who use full dentures, where adaptation and adjustment can be made and guidelines for good hygiene and adjacent care can be established, in addition to maintaining a systematic review of the oral cavity every 3 months.

\section{Diagnosis and treatment of osteonecrosis due to the use of bisphosphonates}

The presence of osteonecrosis may manifest some clinical symptoms, such as pain, sweating, paresthesia, suppuration, soft tissue ulceration, intra and/or extra-oral fistula, abscesses, tooth loss, mobility, maxillary sinus involvement, pathological fracture of the mandible. When the necrosis is at an advanced stage, it may present with an ill-defined radiolucidal radiographic image, moth-eaten appearance, with or without central radiopaque sequestration [33, 39].

After diagnosis, it is possible to divide osteonecrosis into four stages:

0: Necrosis / not apparent bone exposure; intraoral fistula; deep periodontal pocket; small osteolytic lesion on radiograph.
1: Necrosis / apparent bone exposure; asymptomatic; no infection.

2: Necrosis / bone exposure; infection; with or without suppuration; ache.

3: Stage number 2 increased; extent of necrosis; pathological fractures; extraoral fistula, bucosinusal communication [36].

For each stage, there is a specific treatment:

0: Mouthwashes with chlorhexidine; good oral hygiene; fistula or pouch cleaning; antibiotics.

1: Same behavior as stage number 0 .

2: Same stage 0 procedures and antibiotics for three weeks.

3: Soft tissue curettage without exposing bone; good nutrition with supplements or transfusion; curettage or surgical removal of the necrotic area and antibiotic therapy for three weeks [36].

Regarding surgeries, the best recommendation is to postpone as much as possible, if necessary, restricting only the affected area. An adjunctive treatment is to cover the bone necrosis with a resorbable collagen membrane to improve healing. The uses of hyperbaric chambers have shown improvements in terms of neutralizing anti-angiogenic effects, bacterial activity and aiding in healing. Laser therapy has also been used, due to its biostimulant properties, it helps to increase the organic matrix of the bone, stimulates the growth of vessels [31, 33, 36, 39]. 


\section{Discussion and Conclusion}

It is recommended that the patient who uses BFs visit the dentist at least once a year, for better control and monitoring of oral health. The professional must avoid tooth extractions and control the patient's periodontal disease to avoid a future need for tooth extraction. Trauma injuries should be avoided, especially those caused by dental prostheses, especially in the lingual region.

It is of great importance to carry out a complete anamnesis in patients who use BFs, obtaining the most complete data possible for planning and conducting the dental treatment, some data with the use of medication in the bisphosphonate category, such as time of use, dosage, systemic changes, and keep contact with the physician responsible for the prescription.

Prior dental appointments should aim at the total elimination of any possible source of infection, seeking to reduce the accumulation of bacterial plaque, control periodontal inflammation, eliminate cavities and deficient restorations, guidance for proper oral hygiene, as well as perfect fit for maladaptive dentures. In patients in whom bisphosphonates have already been administered, the main orientation is to avoid, whenever possible, extractions and, when really necessary, they should be done trying to cause minimal trauma [46].

Professionals who prescribe BFs should inform the patient about the risk of developing osteonecrosis after performing surgical and rehabilitative procedures in the oral cavity.

Prevention is the main way to avoid BF-related osteonecrosis, so patients should be advised to seek a dentist before, during and after starting therapy with this drug.

\section{References}

[1] Castro LF, Silva ATA, Chung MC, Ferreira AG, Ferreira EI. Bifosfonatos (BFs) coma transportadores osteotrópicos no planejamento de farmacos dirigidos. Quimica Nova. 2004, 27;(3):456-460.

[2] Marx RE, Cillo JE, Ulloa JJ. Oral Bisphosphonate-lnduced Osteonecrosis: Risk Factors, Prediction of Risk Using Serum CTX Testing, Prevention, and Treatment. Journal of Oral and Maxillofacial Surgery. 2007,65(12);23972410.

[3] Dannemann C, Grätz KW, Riener MO, Zwahlen RA. Jaw osteonecrosis related to bisphosphonate therapy: a severe secondary disorder. Bone. 2007 Apr;40(4):828-34. doi: 10.1016 / j.bone.2006.11.023.

[4] Pazianas M, Cooper C, Ebetino FH, Russell RG. Long-term treatment with bisphosphonates and their safety in 
postmenopausal osteoporosis. Ther Clin Risk Manag. 2010 Jul 21;6:325-43. doi: $10.2147 /$ tcrm.s8054.

[5] Scarpa L, Leite LCM, Lacerda JCT. de, Arantes DCB. Osteonecrose nos ossos da maxila e mandíbula associada ao uso do bifosfonato de sódio. Revista Brasileira De Pesquisa Em Saúde/Brazilian Journal of Health Research. 2010,12(1).

[6] Izquierdo CM, Oliveira MG, Weber JBB. Terapeutica com bisfosfonatos: implicagoes no paciente odontol6gico revisao de literatura. RFO. 2011, 16(3):347-352.

[7] de-Freitas NR, Lima LB, de-Moura MB, Veloso-Guedes CC, SimamotoJúnior PC, de-Magalhães D. Bisphosphonate treatment and dental implants: A systematic review. Med Oral Patol Oral Cir Bucal. 2016 Sep 1;21(5):e644-51. doi: 10.4317/ medoral.20920.

[8] Brunton L, Lazo J, Parker K. Goodman \& Gilman's The Pharmacological Basis of Therapeutics. 11. ed. New York: Goodman, 2011. 2084 p.

[9] Russell RG. Bisphosphonates: mode of action and pharmacology. Pediatrics. 2007 Mar;119 Suppl 2:S150-62. doi: 10.1542/peds.2006-2023H.

[10] Netto HDMC, Lisboa RB, Ortega RL, Mazzonetto R. Osteonecrose mandibular ap6s terapia por implantes osseointegrados decorrente do uso do bifosfonato: revisão de literatura e relato de caso. Implantnews.2007, 4:427-30.

[11] Assael LA. New foundations in understanding osteonecrosis of the jaws. J Oral Maxillofac Surg. 2004 Feb;62(2):125-6. doi: 10.1016 / j.joms.2003.11.009.

[12] Bortolini MP. Bisfosfonatos na Odontologia. 2009. 42 f. Monografia (Especialização) - Curso de Especialização em lmplantodontia, Odontologia, Universidade Tuiuti do Parana, Curitiba, 2009.

\section{[13] American Dental Association} Council on Scientific Affairs - ADA. Dental management of patients receiving oral bisphosphonate therapy: expert panel recommendations. The Journal of the American Dental Association, 2006;137(8), p. 1144-1150.

[14] Braun E, Iacono VJ. Bisphosphonates: a review of pharmacology and implications for patient management. Perio Clin Investig. 2005;1:1-20.

[15] Senel FC, Saracoglu Tekin U, Durmus A, Bagis B. Severe osteomyelitis of the mandible associated with the use of non-nitrogen-containing bisphosphonate (disodium clodronate): report of a case. J Oral Maxillofac Surg. 2007 Mar;65(3):562-5. doi: 10.1016/j.joms.2006.10.043.

[16] Maahs, MAP. Associa ao entre o uso de bisfosfonatos e osteonecrose dos 
maxilares: estudo em ratos. 2008. $89 \mathrm{f}$. Tese (Doutorado) - Curso de Doutorado em Estomatologia Clinica, Odontologia, Universidade Cat6Iica do Rio Grande do Sul, Porto Alegre, 2008.

[17] Martins MAT, Giglio AD, Martins MD, Pavesi VCS, Lascala CA.

Osteonecrose dos maxilares associada ao uso de bisfosfonatos: importante complicação do tratamento oncológico. Rev Bras Hematol, 2009; 31(1):41-46.

[18] Badros A, Weikel D, Salama A, Goloubeva O, Schneider A, Rapoport A, Fenton R, Gahres N, Sausville E, Ord R, Meiller T. Osteonecrosis of the jaw in multiple myeloma patients: clinical features and risk factors. J Clin Oncol. 2006 Feb 20;24(6):945-52. doi: 10.1200/JCO.2005.04.2465.

[19] Chaudhry AN, Ruggiero SL. Osteonecrosis and bisphosphonates in oral and maxillofacial surgery. Oral Maxillofac Surg Clin North Am. 2007 May;19(2):199-206, vi. doi: 10.1016/j.coms.2007.01.005.

[20] Fernandes C, Leite RS, Lanças FM. Bisfosfonatos: Sintese, Análises químicas e aplicações farmacológicas. Quim. Nova. 2005, 28(2):274-280.

[21] Marx RE. Pamidronate (Aredia) and zoledronate (Zometa) induced avascular necrosis of the jaws: a growing epidemic. J Oral Maxillofac Surg. 2003 Sep;61(9):1115-7. doi: 10.1016/s02782391(03)00720-1.
[22] Caldas RJ, Pontes JRM, Antunes HS. Osteonecrose dos maxilares induzida par bisfosfonatos: relato de caso clinico. Revista Brasileira de Cancerologia, 2009;55(2):151-155.

[23] Filleul O, Crompot E, Saussez S. Bisphosphonate-induced osteonecrosis of the jaw: a review of 2,400 patient cases. J Cancer Res Clin Oncol. 2010 Aug;136(8):1117-24. doi: 10.1007/s00432010-0907-7.

[24] Migliorati CA, Casiglia J, Epstein J, Jacobsen PL, Siegel MA, Woo SB. 0 tratamento de pacientes com osteonecrose associada aos bifosfonatos: uma tomada de posigao da Academia Americana de Medicina Oral. JADA.2006;6(3):16.

[25] Melo AC, Bastos M, Bastos MR, Loureiro AS, Araújo SS. Osteonecrose da mandibula em paciente portador de mieloma multiple: patologia secundaria ao uso do pamidronato. Revista Brasileira de Hematologia e Hemoterapia. 2005;27(3):221-222.

[26] Bagan JV, Jimenez Y, Murillo J, Hernandez S, Poveda R, Sanchis JM, Diaz JM, Scully C. Jaw osteonecrosis associated with bisphosphonates: multiple exposed areas and its relationship to teeth extractions. Study of 20 cases. Oral Oncol. 2006 Mar;42(3):327-9. doi: 10.1016 / j.oraloncology.2005.08.001. [30] Mehrotra B, Ruggiero SL. Bisphosphonate related osteonecrosis 
(BRON) of the jaw: single institutional update. Blood. 106: 291, 2005.

[27] Holzinger D, Seemann R, Klug C, Ewers R, Millesi G, Baumann A, Wutzl A. Long-term success of surgery in bisphosphonate-related osteonecrosis of the jaws (BRONJs). Oral Oncol. 2013 Jan;49(1):66-70. doi: 10.1016/j.oraloncology.2012.07.008.

[28] Assael LA. Oral bisphosphonates as a cause of bisphosphonate-related osteonecrosis of the jaws: clinical findings, assessment of risks, and preventive strategies. J Oral Maxillofac Surg. 2009 May;67(5 Suppl):35-43. doi: 10.1016/j.joms.2009.01.003.

[29] Neville BW, et al. Patologia oral e maxilofacial. 3 ed. Rio de Janeiro: Elsevier, 2009.

[30] Rogers SN, Hung J, Barber AJ, Lowe D. A survey of consultant members of the British Association of Oral and Maxillofacial Surgeons regarding bisphosphonate-induced osteonecrosis of the jaws. Br J Oral Maxillofac Surg. 2009 Dec;47(8):598-601. doi: 10.1016/j.bjoms.2009.07.020.

[31] Lazarovici TS, Yahalom R, Taicher S, Schwartz-Arad D, Peleg O, Yarom N. Bisphosphonate-related osteonecrosis of the jaw associated with dental implants. J Oral Maxillofac Surg. 2010 Apr;68(4):790-6. doi: 10.1016 / j.joms.2009.09.017.
[32] Yoneda T, Hagino H, Sugimoto T, Ohta H, Takahashi S, Soen S, Taguchi A, Toyosawa S, Nagata T, Urade M. Bisphosphonate-related osteonecrosis of the jaw: position paper from the Allied Task Force Committee of Japanese Society for Bone and Mineral Research, Japan Osteoporosis Society, Japanese Society of Periodontology, Japanese Society for Oral and Maxillofacial Radiology, and Japanese Society of Oral and Maxillofacial Surgeons. J Bone Miner Metab. 2010 Jul;28(4):365-83. doi: 10.1007/s00774-010-0162-7.

[33] Wutzl A, Pohl S, Sulzbacher I, Seemann R, Lauer G, Ewers R, Drach J, Klug C. Factors influencing surgical treatment of bisphosphonate-related osteonecrosis of the jaws. Head Neck. 2012 Feb;34(2):194-200. doi: 10.1002/hed.21708.

[34] Bauer JS, Beck N, Kiefer J, Stockmann P, Wichmann M, Eitner S. Awareness and education of patients receiving bisphosphonates. J Craniomaxillofac Surg. 2012 Apr;40(3):277-82. doi: 10.1016/j.jcms.2011.04.011.

[35] Vescovi P, Merigo E, Meleti M, Manfredi M, Guidotti R, Nammour S. Bisphosphonates-related osteonecrosis of the jaws: a concise review of the literature and a report of a single-centre experience with 151 patients. J Oral Pathol Med. 2012 Mar;41(3):214-21. doi: 10.1111 / j.1600-0714. 2011. 01091.x. 
[36] Mozzati M, Arata V, Gallesio G. Tooth extraction in osteoporotic patients taking oral bisphosphonates. Osteoporos Int. 2013 May;24(5):1707-12. doi: 10.1007/s00198-012-2239-8.

[37] Silva LG, Goldenberg M. A mastigação no processo de envelhecimento. Revista CEFAC. 2001;3:27-35.

[38] Fajardo RS, Neto CLMM, Santos DM, Goiato MC. Analise das condições funcionais e psicol6gicas em pacientes edentulos portadores de pr6teses totais. Arq Odontol.2002;38(2):87-94.

[39] Fazito LT, Perim JV, Di Ninno CQMS. Comparação das queixas alimentares de idosos com e sem pr6tese dentaria. Rev CEFAC. 2004;6(2):143-150.

[40] Zanata A, Felin GC, De Bona MC, Sawazaki R, De Conto F. Osteonecrose mandibular associada ao uso de bisfosfonato de s6dio em paciente com mieloma multiple. Revista Portuguesa de Estomatologia, Medicina Dentaria e Cirurgia Maxilofacial. 2014;55(2):115120.

[41] Gegler A, Cherubini K, Figueiredo MAZ, Yurgel LS, Azambuja AA. Bisfosfonatos e osteonecrose maxilar: revisao da literatura e relato de dais casos. Revista Brasileira de Cancerologia. 2006;52(1):25- 31.

[42] Dotto ML, Dotto AC. Osteonecrose dos maxilares induzida par bisfosfonatos - revisão de literatura e relato de caso. RFO. 2011;16(2):229-233.

[43] Aiex LS, Jimenez M VJ, Milena AP. Osteonecrose mandibular relacionada com bifosfonatos orais em paciente idosa polimedicada. Revista Brasileira de Medicina de Família e Comunidade. 2015;10(36):1-7.

[44] Ruggiero SL, Dodson TB, Fantasia J, Goodday R, Aghaloo T, Mehrotra B, O'Ryan F; American Association of Oral and Maxillofacial Surgeons. American Association of Oral and Maxillofacial Surgeons position paper on medicationrelated osteonecrosis of the jaw--2014 update. J Oral Maxillofac Surg. 2014 Oct;72(10):1938-56. doi: 10.1016/j.joms.2014.04.031.

[45] Heras Rincón I, Zubillaga Rodríguez I, Castrillo Tambay M, Montalvo Moreno JJ. Osteonecrosis of the jaws and bisphosphonates. Report of fifteen cases. Therapeutic recommendations. Med Oral Patol Oral Cir Bucal. 2007 Aug 1;12(4):E267-71.

[46] Brozoski MA, Traina AA, Deboni, MCZ, Marques MM, Naclério-Homem MG. Osteonecrose maxilar associada ao uso de bisfosfonatos. Revista Brasileira de Reumatologia. 2012;2(52):260- 270.

[47] Castilho LS, Lisboa SM, Costas LN, Vilaça EL, Souza ME, Silveira RR. Considerações sabre o paciente em tratamento com bisfosfonatos: o que 
todo cirurgiao-dentista precisa saber.

Revista CROMG. 2013;14(1):19-24.

[48] Graham R, Russell G.

Bisphosphonates: Mode of Action and Pharmacology. Pediatrics. 2007;119:150162.

Conflict of interest: The author declares no conflicts of interest.

Acknowledgements: None.

Funding: None.

How to cite this article: Maganhoto AS, Margute TG, Silva TQM, Rosato AR, Santos IF, Margute TG. Considerations about bisphosphonate therapy and patients using dental prosthesis: a literature review. Brazilian Journal of Case Reports. 2021 Jul-Sep; 01(3):103115. 